\title{
The Influence of Systemic Inducing Resistance Chemicals for the Control of Oak Powdery Mildew (Microsphaera alphitoides) Applied as a Therapeutic Treatment
}

\author{
Glynn Percival and lan Haynes
}

\begin{abstract}
A 2 year field trial was conducted using established English oak (Quercus robur L.) to assess the efficacy of four commercially available systemic-inducing resistance (SIR) compounds (salicylic acid, potassium phosphite, harpin protein, betaine) applied as a single therapeutic spray treatment against the foliar pathogen oak powdery mildew (Microsphaera alphitoides). In addition, a comparative evaluation of a conventional spray program ( 3 week spray intervals) used within the United Kingdom for powdery mildew control was conducted using the fungicide penconazole. The SIR-inducing compound containing betaine and a single spray treatment of penconazole had no significant influence on disease severity and specific activity of peroxidase and superoxide dismutase in both the 2005 and 2006 trials. Salicylic acid and potassium phosphite had no significant long-term effect on disease severity, although a short-term reduction in disease severity was recorded that was associated with enhanced leaf peroxidase and superoxide dismutase activity. A single therapeutic application of the SIR-inducing agent harpin protein significantly reduced disease severity of powdery mildew in the 2005 trial. No significant effects, however, were recorded in the 2006 trial. Only repeat spray applications of penconazole significantly reduced disease severity of oak powdery mildew in the 2005 and 2006 trials. The fungicide penconazole appears also to posses marginal SIR properties.

Key Words. Antioxidant pigments; defensive enzymes; fungicides; integrated disease management; pathogen control; plant health care; urban landscapes.
\end{abstract}

Oak (Quercus spp.) are highly susceptible to the foliar disease powdery mildew (Microsphaera alphitoides Griffon and Maubl.). Conventional control of powdery mildew requires the application of 10 to 22 fungicide applications per season depending on weather conditions (Hibbard et al. 1996; Sabri et al. 1997). The potential for plant pathogens to overcome or to develop insensitivity to conventional fungicides and increased legislative restrictions regarding the use and application of pesticides means new techniques of tree pathogen control are of environmental and economic importance (Agostini et al. 2003).

Plants can defend themselves against pathogen infection through a wide variety of mechanisms that can be local, constitutive, or inducible (Franceschi et al. 2000). Inducible resistance mechanisms such as systemic-induced resistance (SIR) can be acquired by challenging a plant with a weaker strain of a specific pathogen or exposing a plant to natural and/or synthetic compounds (Percival 2001). Formulations of commercial SIRinducing chemicals such as Messenger (Eden Bioscience Corp., N. Bothell, WA) in the United States, Bion (Syngenta Crop Protection UK Ltd., Whittlesford, Cambridge, U.K.) in Europe, Agri-Fos (Agrichem Ltd., Queensland, Australia) in Australia and the United States, and Oryzemate ${ }^{\circledR}$ (Meiji Seika Kaisha, Ltd., Yokohama, Japan) in Japan now exist. Several studies have found these SIR-inducing compounds to be effective in reducing severity of key tree pathogens such as fireblight (Erwinia carotovora), Phytophthora root rot (P. palmivora), powdery mildew (Sphaerotheca pannosa var. rosa, Phyllactinia spp. and Uncinula necator), and wilt disease of spruce (Ceratocystis polonica) (Christiansen et al. 1999; Percival 2001). Importantly, the level of disease control achieved was comparable with currently used agrochemicals. Unlike conventional fungicides, a "one-off" SIR application has been shown to provide growing season protection (Kessmann et al. 1994).

RESISTIM is a plant stimulant and fertilizer combined with natural plant betaines (www.mandops.co.uk/resistim.htm). Betaines are naturally occurring amino acid derivatives that function as osmoprotectants within plants (McNeil et al. 1999). Osmoprotectants serve to raise osmotic pressure in the cytoplasm and stabilize proteins and membranes when salt levels or temperatures are unfavorable for plant growth. Osmoprotectants, therefore, play important roles in the adaptation of cells to adverse environmental conditions (Yancey 1994). Manufacturers claim RESISTIM is particularly effective on legumes such as peas and beans, strengthening them against diseases such as mildew (www.mandops.co.uk/resistim.htm). However, a definitive role for betaine as an inducer of plant defense responses has not been clearly shown. More likely, enhanced levels of betaine are as a consequence of pathogen invasion rather than as a cause of resistance (Berglund and Ohlsson 1995).

Phosphites exhibit a complex mode of action, acting both directly on the pathogen and indirectly by stimulating plant host defense responses such as phenolic accumulation that in turn inhibit pathogen growth (Guest and Grant 1991). Likewise, salicylic acid is widely recognized as an inducer of SIR resistance (Enyedi and Raskin 1993) and is shown to be effective in reducing disease incidence against Phytophthora palmivora in cacao, Pseudomonas syringae pv. Maculicola on cucumber and Arabidopsis, and Colletotrichum lagenarium on cucumber and tobacco necrosis virus (Rasmussen et al. 1991; Kessmann et al. 1994; Okey and Sreenivan 1996).

Harpin protein is a naturally occurring bacterial protein present in several plant pathogenic bacteria to include Erwinia amy- 
lovora responsible for fireblight in apples. Manufacturers claim harpin proteins possess wide activity against a broad range of pathogenic viral, bacterial, and fungal diseases and, in addition, enhance resistance to insect attack (www.yardener.com/ HarpinProteinProducts.html).

Enhanced leaf peroxidase activity has been associated with SIR against tobacco mosaic virus, alfalfa mosaic virus, and $P h y$ tophthora cinnamomi (Van Lelyveld and Brodrick 1975; Vegetti et al. 1975; Van Loon 1976). Induced systemic resistance against, for example, the pathogens Colletotrichum lagenarium and Cladosporium cucumerinum is associated with an enhanced ability of the host plant to lignify at points of fungal penetration. Lignification involves the polymerization of hydroxycinnamyl alcohols mediated by peroxidase in the presence of hydrogen peroxide (Gross 1979; Dalisay and Kuc 1995). Likewise, treatment of the lower leaves of potato plants with hyphal wall components of Phytophthora infestans systemically activated enhancement of superoxide dismutase resulting in a significant reduction of hyphal penetration and susceptible lesions (Chai and Doke 1987).

Investigations into SIR-inducing compounds to control oak powdery mildew have received limited study. In addition, the majority of studies regarding the efficacy of SIR-inducing chemicals have been conducted primarily under laboratory and glasshouse conditions that do not reflect field or landscape environments. Finally, assessments of SIR efficacy in the majority of cases reflect applications applied as preventive (before visible symptoms of diseases expression) rather than therapeutic (when disease expression is visible). The objectives of this project were to investigate 1) the efficacy of commercially available SIR compounds on powdery mildew infection of English oak under field conditions as therapeutic rather than preventive treatments; and 2) the role of leaf peroxidase and superoxide dismutase activity on powdery mildew infection.

\section{MATERIALS AND METHODS}

\section{Plant Material and Experimental Design}

The trial site consisted of a 2.0 ha block of English oak (Quercus robur L.) at the University of Reading Shinfield Experimental Site, Berkshire, U.K. Planting distances were based on a $2 \times 1 \mathrm{~m}$ $(6.6 \times 3.3 \mathrm{ft})$ spacing. Trees were planted in early November 2001 and trained to produce a central-leader system to an average height of $1.5 \pm 0.15 \mathrm{~m}(4.95 \pm 0.5 \mathrm{ft})$ with mean trunk diameters of $10 \pm 2 \mathrm{~cm}(4 \pm 0.8 \mathrm{in})$. Weeds were controlled with glyphosate (Roundup; Green-Tech, Sweethills Park, Nun Monkton, York, U.K.) applied at $15 \mathrm{~mL}(0.45 \mathrm{fl} \mathrm{oz})$ per liter $(0.26 \mathrm{gal})$ of water four times during the growing season. Supplementary irrigation was applied during the 2005 and 2006 growing seasons as required. Trees were fertilized annually through a broadcast application of granular 29N-7P-9K fertilizer (Bartlett BOOST; The Doggett Corporation, Lebanon, NJ, U.S.) applied at $40 \mathrm{~g} \mathrm{(1.4 \textrm {oz } )}$ $\mathrm{m}^{2}\left(11 \mathrm{ft}^{2}\right)$ in early May. The soil was a sandy loam containing $4 \%$ to $6 \%$ organic matter, $\mathrm{pH}$ of 6.2 ; available phosphorus, potassium, magnesium, sodium, and calcium were 52.0, 659.1, 175.2, 49.4 , and $2188 \mathrm{mg} / \mathrm{L}(0.0001,0.005,0.002,0.0001$, and $0.02 \mathrm{oz} /$ gal), respectively, at the time treatments began.

Historically, the oaks suffered annually from powdery mildew infections. Consequently, before the trial began in 2005 and 2006, trees were inspected in September 2004 and 2005 and only those trees visually rated with $50 \%$ to $80 \%$ of leaves affected, representing severe foliar discoloration and powdery mildew in- fection, were used in the 2005 and 2006 trial. The insecticide deltamethrin (Bandu; Headland Agrochemicals Ltd., Saffron Walden, Essex, U.K.) was applied every 3 months during each growing season beginning in May 2005 to September 2006 to control pests. All sprays were applied using a Tom Wanner Spray Rig sprayer at $40 \mathrm{~mL}(1.2 \mathrm{fl} \mathrm{oz})$ deltamethrin per $100 \mathrm{~L}$ (26 gal) of water. Trees were sprayed until runoff, generally $0.25 \mathrm{~L}$ (0.07 gal) deltamethrin per tree.

\section{Systemic-Inducing Resistance Treatments}

Seven trees with $5 \%$ to $20 \%$ of leaves affected with powdery mildew, i.e., some yellowing but little or no defoliation, were treated per SIR product. This occurred on 23 July 2005 and 31 July 2006. During SIR spray treatments, polythene screens $1 \mathrm{~m} \mathrm{(3.3 \textrm {ft } )}$ high were erected around each tree to prevent dispersal of sprays and possible cross-contact with other trees. The base of the tree was covered with a $0.5 \mathrm{~m} \times 0.5 \mathrm{~m}(1.65 \times 1.65 \mathrm{ft})$ polythene mulch to prevent potential soil percolation. The treatments (Messenger [herapin protein], Agri-Fos [potassium phosphate], Asprin [salicylic acid], RESISTIM [Betaine, amino acid derivatives], two fungicide [penconazole] regimes, and a water control) were applied in seven randomized complete blocks with a single tree as the experimental unit, giving a total of 49 observations per response variable. Foliar sprays of each chemical were applied until runoff using a $10 \mathrm{~L}$ (2.6 gal) backpack sprayer at the manufacturer's recommended rate:

RESISTIM (a.i. betaine): $10 \mathrm{~mL}(0.3 \mathrm{fl} \mathrm{oz})$ per liter $(0.26 \mathrm{gal})$ of water (Mandops UK Ltd., Eastleigh, Hampshire, U.K.);

Topas (a.i. penconazole): $1.5 \mathrm{~mL}(0.045 \mathrm{fl} \mathrm{oz})$ per liter $(0.26 \mathrm{gal})$ of water (Syngenta Crop Protection UK Ltd., Whittlesford, Cambridge, U.K.); Messanger (a.i. harpin protein): $4 \mathrm{~g}(0.14 \mathrm{oz})$ per $100 \mathrm{~m}^{2}(1,111 \mathrm{sq} \mathrm{ft})$ (EDEN Bioscience Corporation, N. Bothell, WA);

Agri-Fos (a.i. potassium phosphite): $3 \mathrm{~mL}$ ( $0.09 \mathrm{fl} \mathrm{oz}$ ) per liter (0.26 gal) of water (Shelton Technology Ltd., Boundary House, Charwelton, Northamptonshire, U.K.); and

Salicylic acid: $3 \mathrm{~mL}(0.09 \mathrm{fl} \mathrm{oz})$ per liter $(0.26 \mathrm{gal})$ of water (Shelton Technology Ltd.).

In addition, a comparative evaluation of a conventional spray program used within the United Kingdom for powdery mildew control was conducted. Trees were sprayed with the fungicide Topas (a.i. penconazole), a protectant conazole fungicide with antisporulant activity, at the recommended rate of $1.5 \mathrm{~mL}(0.045$ $\mathrm{fl} \mathrm{oz})$ per liter $(0.26 \mathrm{gal})$ of water. Penconazole treatments began at the same time as application of SIR products and every 3 weeks thereafter until the cessation of the experiment (27 September 2005 and 2006).

\section{Disease Severity}

Disease severity of whole trees was assessed visually on 27 September 2005 and 2006. Each tree was rated on a 0 to 5 rating scale using a visual indexing technique and ratings on the scale: $0=$ no powdery mildew observed; $1=$ less than $5 \%$ of leaves affected and no aesthetic impact; $2=5 \%$ to $20 \%$ of leaves affected with some yellowing but little or no defoliation; $3=21 \%$ to $50 \%$ of leaves affected, significant defoliation, and/or leaf yellowing; $4=51 \%$ to $80 \%$ of leaves affected, severe foliar discoloration; and $5=81 \%$ to $100 \%$ of foliage affected with $90 \%$ to $100 \%$ defoliation.

Leaf disease severity was assessed at days 10, 20, and 60 after application of the SIR-inducing chemical to determine the shortand long-term effects of each product using a similar indexing 
technique as follows: $0=$ no powdery mildew observed; $1=$ less than $5 \%$ of leaf surface covered with hyphal growth; $2=5 \%$ to $20 \%$ of leaf surface covered; $3=21 \%$ to $50 \%$ of leaf surface covered; $4=51 \%$ to $80 \%$ of leaf surface covered; and $5=81 \%$ to $100 \%$ of leaf surface covered.

\section{Superoxide Dismutase Activity}

Superoxide dismutase activity (SOD) activity was based on the method described by Kraus and Fletcher (1994). In summary, extracts were prepared at $4^{\circ} \mathrm{C}\left(39.2^{\circ} \mathrm{F}\right)$ by homogenizing $0.2 \mathrm{~g}$ $(0.07 \mathrm{oz})$ of leaf tissue (generally six leaves per tree in $4 \mathrm{~mL}$ [0.12 fl oz] of $0.1 \mathrm{M} \mathrm{Na}_{2} \mathrm{HPO}_{4} / \mathrm{NaH}_{2} \mathrm{PO}_{4}$ buffer [pH 7] with a mortar and pestle and centrifuged at $16,000 \times g$ for $10 \mathrm{~min})$. The supernatant was filtered through Whatman paper (No. 1) and 1 $\mathrm{mL}(0.03 \mathrm{fl} \mathrm{oz})$ was applied to a Pharmacia PD-10 chromatography column containing Sephadex G-250 equilibrated with 50 $\mathrm{mM} \mathrm{Na} \mathrm{CO}_{3}$ buffer ( $\mathrm{pH}$ 10.2) to remove low-molecular-weight components and exchange the buffer. The assay was performed using $0.1 \mathrm{mM}$ diethylenetriaminepentaacetic acid in the reaction mixture and the subsequent increase in absorbance at $550 \mathrm{~nm}$ followed on a spectrophotometer (PU8800 Pye Unicam, Portsmouth, U.K.) equipped with a kinetics module for $6 \mathrm{~min}$ at $24^{\circ} \mathrm{C}$ $\left(75.2^{\circ} \mathrm{F}\right)$. SOD activity was assessed at days 10, 20, and 60 after application of the SIR-inducing chemical to determine the shortand long-term effects of each product on enzymatic activity.

\section{Peroxidase Activity}

A total of $0.3 \mathrm{~g}(0.01 \mathrm{oz})$ of foliar tissue (generally six leaves per

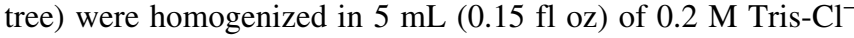
(buffer $\mathrm{pH} 7.8$ ) containing $0.13 \mathrm{mM}$ EDTA and $80 \mu \mathrm{M}$ soluble polyvinylpyrrolidone with a Polytron homogenizer (Glen Mills Inc., Clinton, NJ) for $30 \mathrm{sec}$ on ice and centrifuged at 3,000 $\times g$ for $10 \mathrm{~min}$. Catalase activity was determined by following the consumption of hydrogen peroxide (extinction coefficient 39.4 $\mathrm{mm}^{-1} / \mathrm{cm}^{-1}$ ) at $240 \mathrm{~nm}$ for $2 \mathrm{~min}$. The reaction mixture contained $2 \mathrm{~mL}(0.06 \mathrm{fl} \mathrm{oz})$ of $100 \mathrm{mM} \mathrm{Na} 2 \mathrm{HPO}_{4} / \mathrm{NaH}_{2} \mathrm{PO}_{4}$ buffer $(\mathrm{pH} 6.5)$ and $50 \mu \mathrm{L}$ of plant extract, and the reaction was initiated by adding $10 \mu \Lambda$ of $30 \%$ (w/v) hydrogen peroxide. Leaf peroxidase activity was assessed at days 10, 20, and 60 after application of the SIR-inducing chemical to determine the shortand long-term effects of each product on enzymatic activity.

\section{Statistical Methods}

Before the analysis, data were examined to ensure normality and homogeneity of variance (Anderson-Darling test) were met to meet the assumptions for the analysis of variance. Data were then analyzed as a randomized complete block using an analysis of variance (ANOVA). If trial data violated the basic assumptions required by ANOVA, data were log-transformed and then backtransformed for presentation in tables. Differences in levels of disease severity, leaf superoxidase dismutase, and peroxidasespecific activity from control values were determined and means were separated at the $P<0.05$ level of significance using the Genstat for Windows program (VSN International Ltd., Hemel Hempstead, U.K.). A simple linear mathematical model was used to record relationships between leaf superoxidase dismutase and peroxidase-specific activity versus leaf disease severity using goodness-of-fit $\mathrm{R}^{2}$ values.

\section{RESULTS}

In both the 2005 and 2006 trials, damaging outbreaks of powdery mildew were recorded on control trees as indicated by disease severity ratings of 5.0 to 5.5, respectively, on leaves of English oak (Figure 1). During the study, none of the treated or control trees died as a result of pathogen attack. None of the SIR agents or fungicide evaluated was phytotoxic to the test trees. The SIRinducing compound RESISTIM (a.i. betaine) and a single spray treatment of penconazole had no significant influence on disease severity and specific activity of peroxidase and superoxide dismutase in both the 2005 and 2006 trials (Figures 1 to 4). Consequently, results for RESISTIM are shown that reflect those of a single penconazole spray treatment. Results of this study indicate that the commercially available compound RESISTIM and a single spray of penconazole have no significant role in the control of powdery mildew when applied as a therapeutic treatment (Figure 1).

\section{Disease Severity}

In both the 2005 and 2006 trials, salicylic acid and potassium phosphite had no significant effect on disease severity at the cessation of the growing season (Figure 1). Consequently, results of this study indicate no beneficial long-term effects of salicylic acid and potassium phosphite on reducing powdery mildew severity when used as a single therapeutic spray treatment. Application of the SIR-inducing agent harpin protein significantly $(P<$ 0.05 ) reduced disease severity of powdery mildew from 5.5 to 2.1 in the 2005 trial. No significant effects, however, on disease severity were recorded in the 2006 trial. The fungicide Topas (penconazole) applied at three weekly intervals after the visible observation of powdery mildew resulted in a significant $(P<0.05)$ reduction in disease severity (Figure 1). Disease severity rates in this instance were reduced from 5.5 to 1.9 (2005 trial) and 5.0 to 1.8 (2006) trial.

\section{Leaf Superoxidase Dismutase, Peroxidase-Specific Activity, and Disease Severity}

The SIR-inducing agents harpin protein, salicylic acid, and potassium phosphite increased leaf-specific activity of superoxidase dismutase and peroxidase by $16 \%$ to $28 \%$ at days 10 and 20 postapplication compared and nontreated controls (Figures 2 and 3). In all cases, such an increase in activity was significant at $P<0.05$. By day 60, however, specific activity of both enzymes in leaves was nonsignificant when compared with controls (Figures 2 and 3). Such a result indicates a single spray of harpin protein, salicylic acid, and potassium phosphite induces superoxidase dismutase and peroxidase activity 20 days or more but less than 60 days. Concomitant with an increase in superoxidase dismutase and peroxidase activity at days 10 and 20 , a significant $(P<0.05)$ reduction in disease severity was recorded at these time intervals. Such a result indicates an association between enhanced superoxidase dismutase and peroxidase activity and resistance against oak powdery mildew. Applications of penconazole had no significant effect on specific leaf activity of superoxidase dismutase at days 10,20, and 60, although the level of activity was always higher than controls (Figure 3). However, a significant increase $(P<0.05)$ in leaf peroxidase activity was recorded at days 10 and 20 (Figure 3). At day 60, levels were higher than controls, only not significantly so. At days 10, 20, and 60, penconazole application significantly $(P<0.05)$ reduced disease severity compared with nontreated controls (Figure 4$)$. 


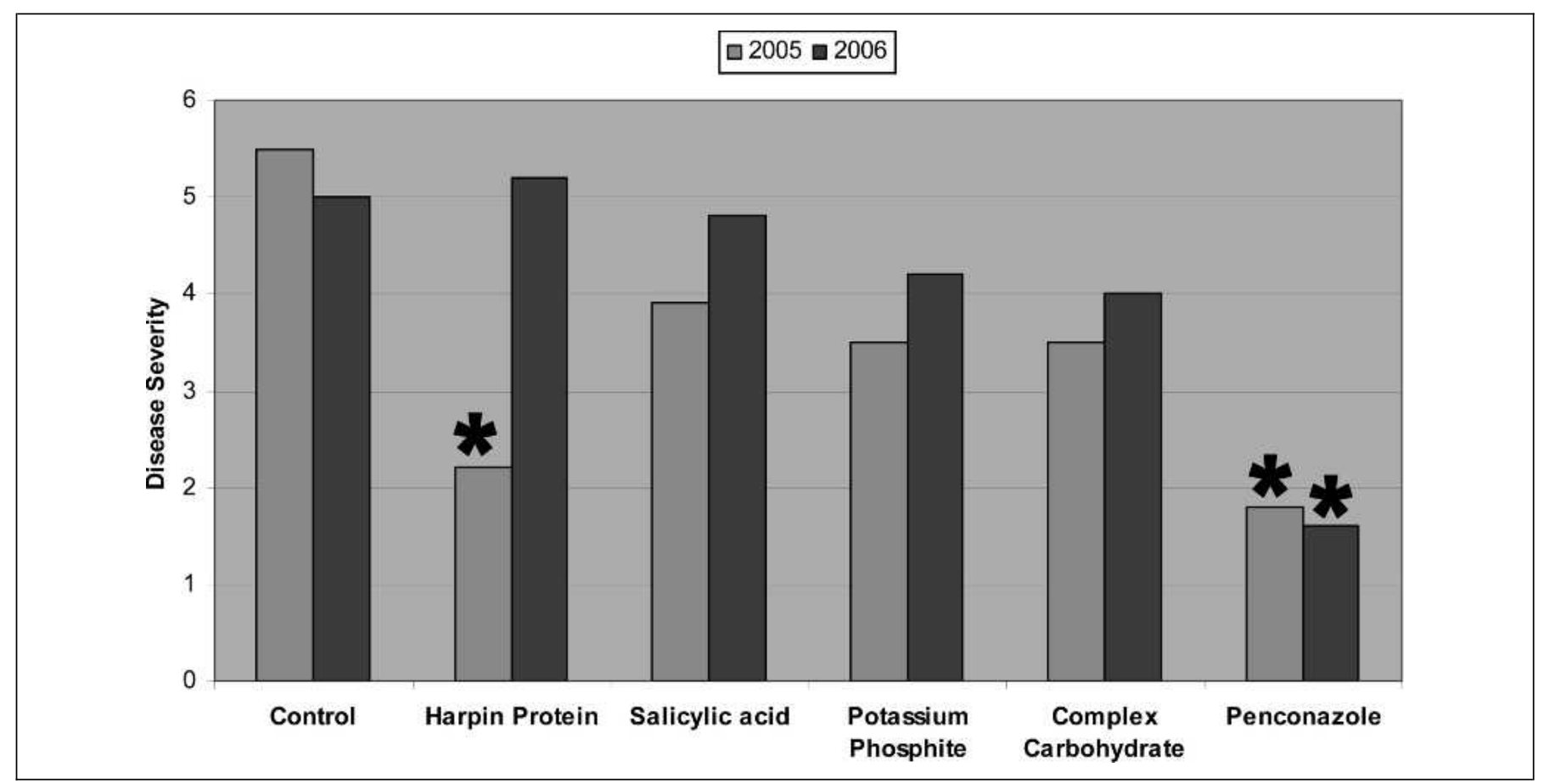

Figure 1. The influence of systemic-inducing resistance (SIR) and a fungicide treatment on disease severity of powdery mildew on English oak growing under field conditions. Trials were conducted in 2005 and 2006. All values mean of seven trees. ${ }^{*}$ Significantly different from controls according to least significant difference at $P<0.05$; no annotations = not significant different from control value. Significance of SIR-inducing agents in $2005=P<0.05$, nonsignificant; significance of SIR-inducing agents in 2006 = nonsignificant (analysis of variance effect).

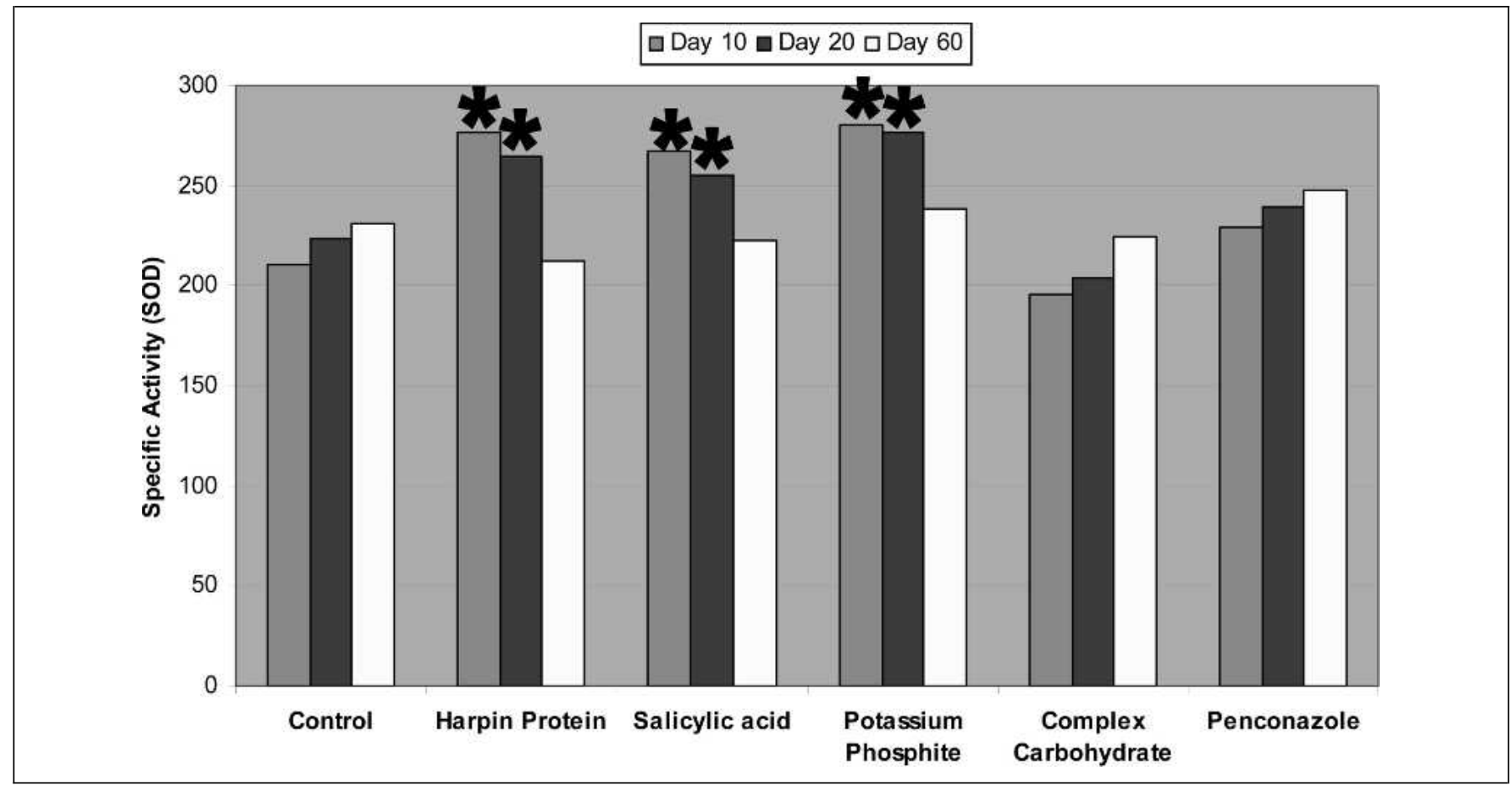

Figure 2. The influence of systemic-inducing resistance (SIR) and a fungicide treatment on leaf superoxidase dismutase activity in English oak at days 10, 20, and 60 after application. Trees were growing under field conditions. Powdery mildew infection was visibly present on the leaf at the time of SIR application (disease severity =2). Measurements were taken only in the 2006 trial. All values mean of seven trees, two superoxidase dismutase measurements per tree with each superoxide dismutase activity measurement comprised of six leaves. " Significantly different from controls according to least significant difference at $P<0.05$; no annotations $=$ not significant different from control value. Significance of SIR-inducing agents at days 10 and $20=P<0.001$ (analysis of variance effect). Significance of SIR-inducing agents at day 60 = nonsignificant (analysis of variance effect). 


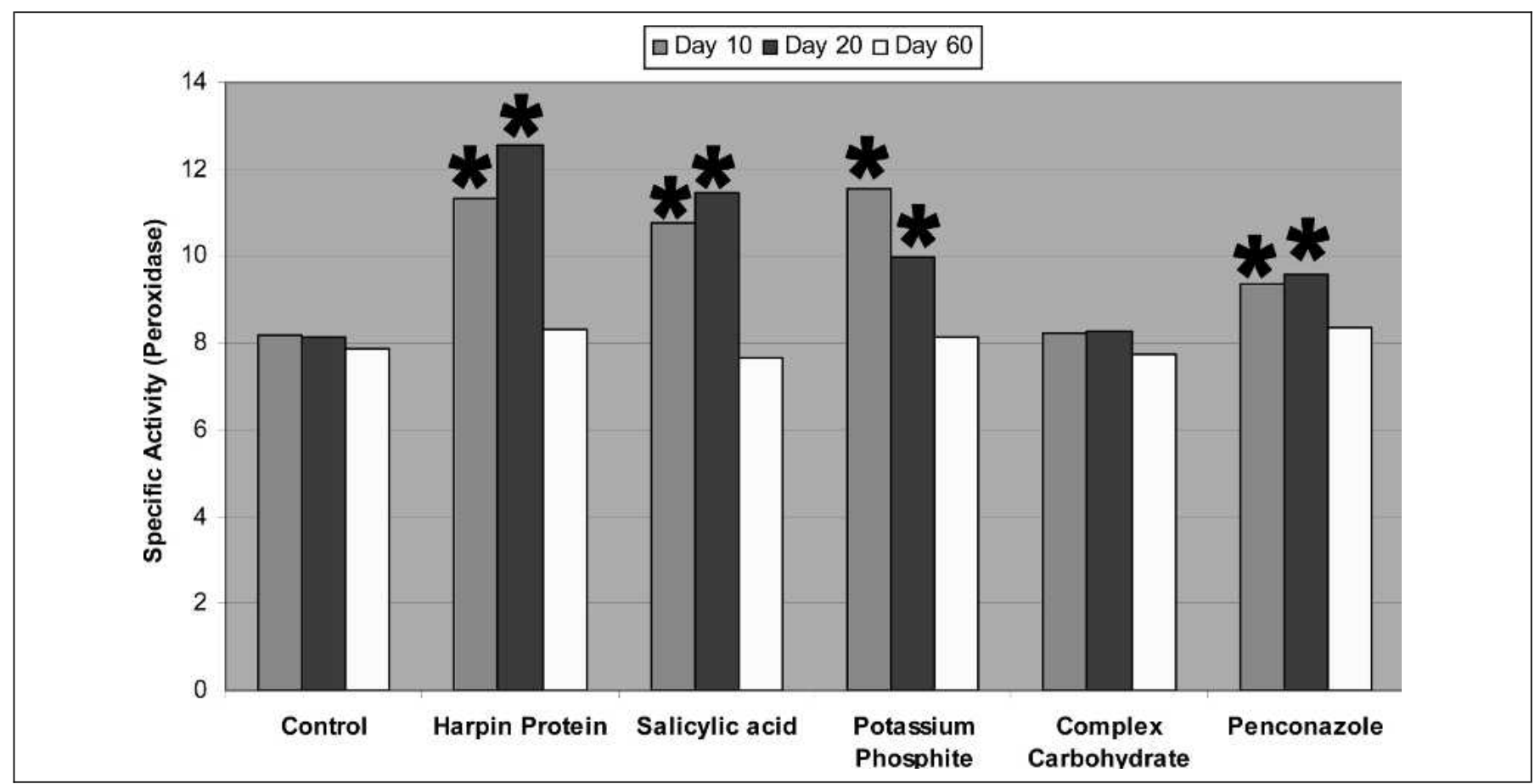

Figure 3. The influence of systemic-inducing resistance (SIR) and a fungicide treatment on leaf peroxidase activity in English oak at days 10, 20, and 60 after application. Trees were growing under field conditions. Powdery mildew infection was visibly present on the leaf at the time of SIR application (disease severity = 2). Measurements were taken only in the 2006 trial. All values mean of seven trees, two peroxidase measurements per tree with each peroxidase measurement comprised of six leaves. ${ }^{*}$ Significantly different from controls according to least significant difference at $P<0.05$; no annotations $=$ not significant different from control value. Significance of SIR-inducing agents at days 10 and $20=P<0.001$ (analysis of variance effect). Significance of SIR-inducing agents at day $60=$ nonsignificant (analysis of variance effect).

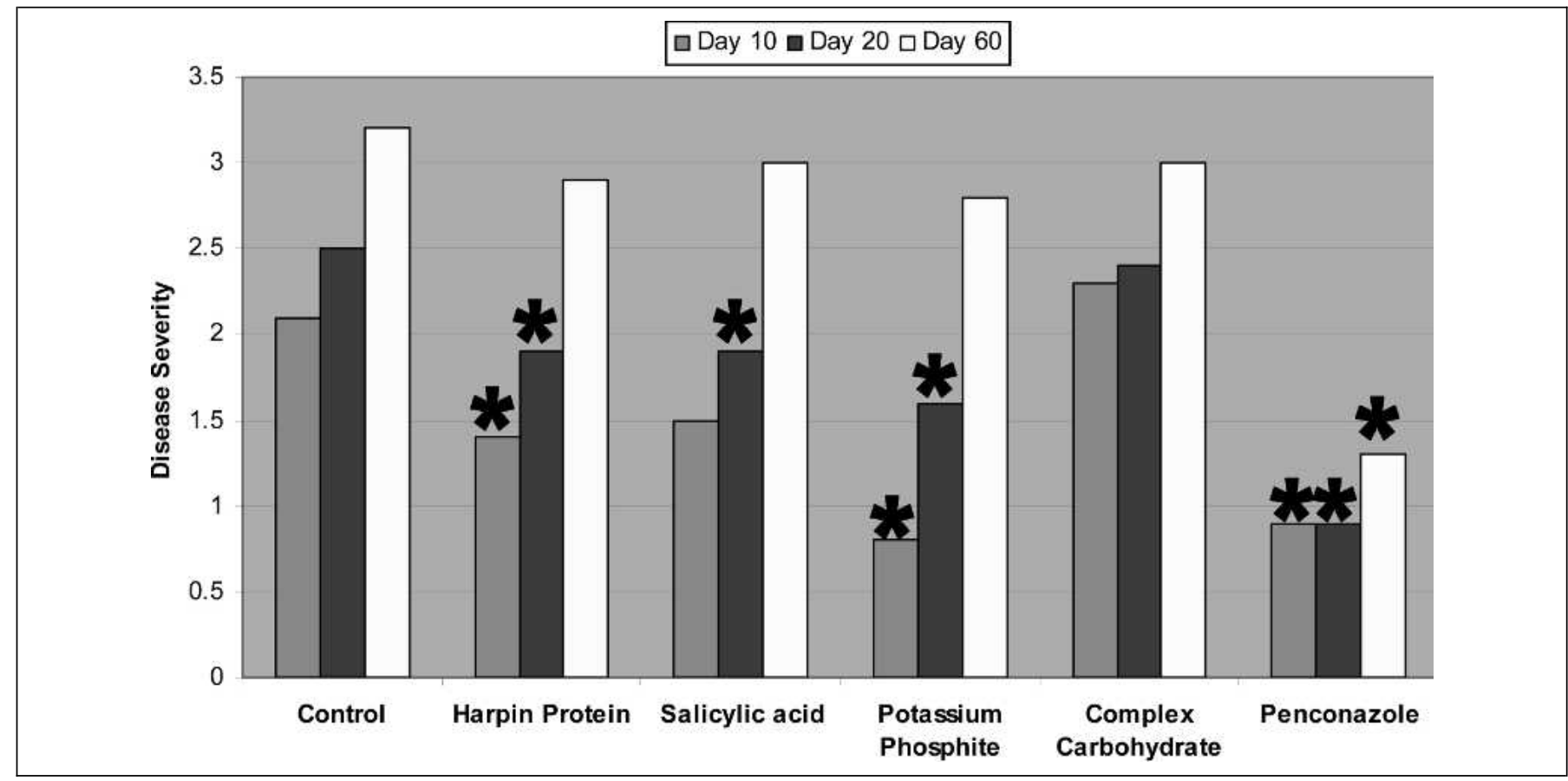

Figure 4. The influence of systemic-inducing resistance (SIR) and a fungicide treatment on leaf disease severity in English oak at days 10, 20, and 60 after application. Trees were growing under field conditions. Powdery mildew infection was visibly present on the leaf at the time of SIR application (disease severity =2). Measurements were taken only in the 2006 trial. All values mean of seven trees, 12 leaves per tree. ${ }^{*}$ Significantly different from controls according to least significant difference at $P<0.05$; no annotations = not significant different from control value. Significance of SIR-inducing agents at days 10 and $20=P<0.001$ (analysis of variance effect). Significance of SIR-inducing agents at day $\mathbf{6 0}=$ nonsignificant (analysis of variance effect). 


\section{Relationship of Leaf Superoxidase Dismutase and Peroxidase-Specific Activity versus Leaf Disease Severity}

Figure 5 shows the relationships between leaf superoxidase dismutase and peroxidase-specific activity versus leaf disease severity. A simple linear mathematical model best fit the relationship between these parameters. Goodness-of-fit $\mathrm{R}^{2}$ values of 0.56 (day 10) and 0.43 (day 20) and 0.59 (day 10) and 0.65 (day 20) were recorded between the specific leaf activity of peroxidase and SOD, respectively, and leaf disease severity (Figure 5). These relationships were highly significant at $P<0.001$. Such a result indicates enhanced levels of peroxidase and SOD activity may contribute to reduced leaf disease severity caused by oak powdery mildew. At day 60 post-SIR application, no relationship was found between peroxidase and SOD activity and leaf disease severity with $\mathrm{R}^{2}$ values of 0.06 and 0.04 recorded coupled with a lower and a nonsignificant $P$ value (Figure 5).

\section{DISCUSSION}

The phenomenon of inducing resistance in plants by biologic and/or natural compounds such as jasmonic acid, salicylic acid (aspirin), phosphates, fatty acids, and so on, potentially offers an alternate, more environmentally benign approach to tree protection (Friedrich et al. 1996; Sticher et al. 1997). Several studies have found SIR-inducing compounds to be effective in controlling fireblight (Erwinia carotovora), Phytophthora root rot $(P$. palmivora), powdery mildew (Sphaerotheca pannosa var. rosa, Phyllactinia spp., and Uncinula necator), and wilt disease of spruce (Ceratocystis polonica) with the level of disease control achieved comparable with currently used agrochemicals (Sparla et al. 2004). Few reports exist evaluating the effects of salicylic acid, potassium phosphite, betaines, and harpin protein on reducing disease severity of oak powdery mildew (Microsphaera alphitoides) under field conditions. Results of this study indicate that salicylic acid, potassium phosphite, and betaine do not provide long-term protection against oak powdery mildew (Microsphaera
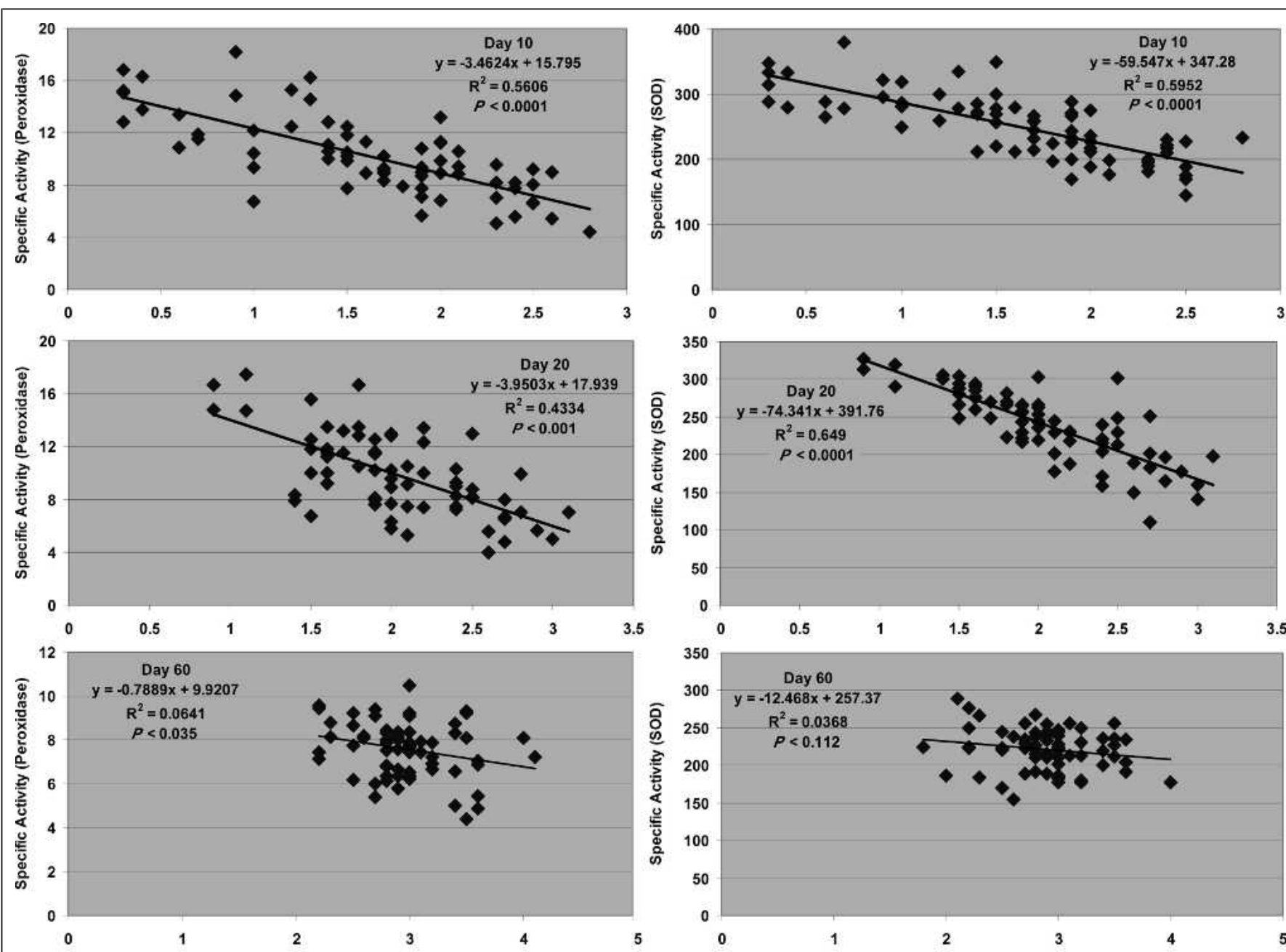

\section{Disease Severity}

Figure 5. Correlation of leaf disease severity versus leaf peroxidase and superoxide dismutase (SOD) activity at days 10,20 , and 60 after spray application of systemic-inducing resistance chemicals. Each value mean of six leaves pooled for a mean leaf disease severity and peroxidase and SOD activity. Two values per tree, i.e., 12 leaves per tree, were collected from seven trees per treatment. 
alphitoides) when applied as a single therapeutic spray treatment. A short-term (20 day) reduction in leaf disease severity was, however, recorded with salicylic acid and potassium phosphite. Research by the author also indicated a single therapeutic spray treatment of the four SIR agents used in this investigation have no longterm effects on disease severity of other foliar pathogens such as apple scab (Venturia inaequalis) and Guignardia leaf blotch (Guignardia aesculi) (Percival, unpublished data).

Induction of antioxidant and defensive enzymes such as superoxidase dismutase and peroxidase are recognized as initial SIR responses in plants (Kessmann et al. 1994). No such response was recorded in this investigation after RESISTIM application indicating no SIR-inducing properties. In addition, no significant role of betaine in the form of RESISTIM in enhancing tree resistance against oak powdery mildew was recorded when applied as a single therapeutic treatment.

Research in Australia and the United States have found phosphites to be effective in the control of diseases, particularly those that belong to the oomycetes group such as Phytophthora spp., Pythium spp., and the Downy Mildew diseases (Jackson et al. 2000; Wilkinson et al. 2001; Miller et al. 2006). In addition, phosphites control other diseases that fall outside this group such as the bacterial disease Erwinia amylovora (apple fireblight). Potassium phosphite has been shown to provide a significant degree of control against Venturia inaequalis when applied as foliar sprays at 10 to 12 day intervals (MacHardy and Jeger 1983). Application of phosphites and salicylic acid as a single therapeutic spray treatment, however, appeared to offer a short-term reduction in disease severity up until day 20 after application, but by the cessation of the growing season, no long-term control of oak powdery mildew under field conditions was recorded.

The use of the harpin protein (trade name Messanger) has been shown to reduce disease severity of Botrytis cinerea on leaves and fruit of pepper (Capsicum annuиm L. var. cvs. 'Demre', 'Yalova Charleston', and 'Sari Sivri') as measured by leaf chlorophyll content (Akbudak et al. 2006). In this study, application of harpin protein provided a significant degree of protection against oak powdery mildew in the 2005 trial. No significant long-term effects, however, were recorded in the 2006 trial. Such a response reflects those recorded by Agostini et al. (2003) who evaluated the influence of harpin protein (Messenger) on enhanced resistance of potted lemon seedlings against citrus scab (Elsinoe fawcettii), grapefruit against melanose (Diaporthe citri), and Dancy tangerine against Alternaria brown spot (Alternaria alternata pv. citri). In the case of Diaporthe citri and (Alternaria alternata pv. citri), no enhanced resistance effects were recorded after application of harpin protein. In the case of citrus scab, Messenger provided a significant degree of control in some studies but not others. A number of reasons were postulated for this lack of consistency. Plant phenology has been shown to be important, with harpin protein showing greater effectiveness when applied at budbreak before inoculum buildup. Efficacy was also influenced by the weather conditions that prevailed at the time of application with cool wet weather not conducive for efficacy (Agostini et al. 2003). The potential shelf life and batch-to-batch variation of biologic propagules in terms of reduced viability has been highlighted by Downer (2007) that may also partially explain the lack of consistency shown by the harpin protein. These problems should not distract from the fact that a single spray treatment of harpin protein during the 2005 growing season provided season-long control of oak powdery mildew comparable with repeat three-weekly applications of a commercially available triazole fungicide. Such a response indicates that further research to clarify phonologic and climatic influences on the efficacy of SIR-inducing chemicals may help develop important tree protectant compounds. In addition, results of this study indicate a short-term (20 day) reduction in leaf disease severity after spray application of harpin protein.

A positive relationship between enhanced leaf peroxidase and superoxide dismutase activities and reduced oak powdery mildew were observed up to 20 days after systemic induction. By day 60 after SIR treatment, however, any induced protection was no longer manifest with disease severity reflecting those of controls. Such a result indicates repeat application of systemic inducement at 20 day intervals may be warranted to enhance resistance against oak powdery mildew over time.

Repeat spray applications of penconazole resulted in a significant increase in peroxidase activity in English oak. Likewise, repeat spray applications of penconazole resulted in higher leaf activities of superoxide dismutase compared with controls, if not significantly so, in all cases. Reductions in disease severity as a result of direct fungicidal properties of penconazole is through inhibition of the C4-demethylase reactions in sterol biosynthesis of fungi (Allingham 2005). However, all triazole-based fungicides have been shown to induce a suite of morphologic adaptations to include promotion of leaf catalase and superoxide dismutase activity that allow plants to tolerate a range of environmental stresses (Kraus and Fletcher 1994). These antioxidant enzymes and pigments are vital in quenching high-energy reactive oxygen species (ROS) such as superoxide and singlet oxygen produced in response to abiotic stresses such as salinity, drought, and atmospheric pollutants (Apel and Hirt 2004). Consequently, a number of authors suggest that triazole-induced protection from abiotic stress is an important factor in improving tree vitality that in turn allows the tree's own natural defense mechanisms to reduce subsequent pathogen attack (Zhang et al. 1994; Fletcher et al. 2000).

In conclusion, results of this investigation indicate that in the case of oak powdery mildew, a positive association was noted between increased activities of peroxidase and superoxide dismutase and reduced disease severity in the short term. Such benefits were, however, not manifest over a longer time period indicating repeat 20 day interval sprays are required. Further research evaluating the influence of repeat SIR treatments are ongoing against a range of foliar and root pathogens.

\section{LITERATURE CITED}

Agostini, J.P., P.M. Bushong, and L.W. Timmer. 2003. Glasshouse evaluation of products that induce host resistance for control of scab, melanose, and Alternaria brown spot of citrus. Plant Disease 87:69-75.

Akbudak, N., H. Tezcan, B. Akbudak, and V. Seniz. 2006. Effect of harpin protein on plant growth parameters, leaf chlorophyll, leaf colour and percentage rotten fruit of pepper plants inoculated with Botrytis cinerea. Scientia Horticulturae 109:107-112.

Allingham, R. 2005. The effect of the growth retardant paclotutrazol on the in vitro growth and development of Betula and Populus species. MSc Thesis, Dept. of Environmental Management, University of Central Lancashire.

Apel, K., and H. Hirt. 2004. Reactive oxygen species: Metabolism, oxidative stress, and signal transduction. Annual Review of Plant Biology 55:373-399.

Berglund, T., and R. Ohlsson. 1995. Defensive and secondary metabolism in plant tissue cultures, with special reference to nicotinamide, 
glutathione and oxidative stress. Plant Cell, Tissue and Organ Culture 43:137-145.

Chai, H.B., and N. Doke. 1987. Systemic activation of $\mathrm{O}^{2}$ generating reaction, superoxide dismutase, and peroxidase in potato plants in relation to induction of systemic resistance to Phytophthora infestans. Annals of the Phytophthological Society of Japan 53:585-590.

Christiansen, E., P. Karokene, A.A. Berryman, V.R. Franceschi, T. Krekling, F. Lieutier, A. Lonneborg, and H. Solheim. 1999. Mechanical injury and fungal infection induce acquired resistance in Norway spruce. Tree Physiology 19:399-403.

Dalisay, R.F., and J.A. Kuc. 1995. Persistence of induced resistance and enhanced peroxidase and chitinase activities in cucumber plants. Physiological and Molecular Plant Pathology 47:315-327.

Downer, J. 2007. Snake oil, horticultural myths, horticultural urban legends and persuaders in our industry. Arborist News 16:30-34.

Enyedi, A.J., and I. Raskin. 1993. Induction of UDP-glucode: Salicylic acid glucosyl-transferase activity in tobacco mosaic virus-inoculated tobacco (nicotiana tabacum) leaves. Plant Physiology 101: 1375-1380.

Fletcher, R.A., A. Gilley, N. Sankhla, and T.D. Davis. 2000. Triazoles as plant growth regulators and stress protectants. Horticultural Reviews 24:55-138.

Franceschi, V.R., P. Karokene, T. Krekling, and E. Christiansen. 2000. Phloem parenchyma cells are involved in local and distant defense responses to fungal inoculation or bark-beetle attack in Norway spruce (Pinaceae). American Journal of Botany 87:314-326.

Friedrich, L., K. Lawton, R. Wilhelm, P. Manser, N. Specker, M. GutRella, B. Meier, S. Dincher, T. Staub, S. Uknes, J.P. Metraux, H. Kessmann, and J. Ryals. 1996. A bendzothiadiazole derivative induces systemic acquired resistance in tobacco. The Plant Journal 10:61-70.

Gross, G.G. 1979. Recent advances in the chemistry and biochemistry of lignin, pp. 177-220. In: Swain, T., J.B. Harborne, and C.F. Van Sumere (Eds.). Biochemistry of Plant Phenolics, Recent Advances in Phytochemistry. Vol. 12. Plenum Press, New York, NY.

Guest, D., and B. Grant. 1991. The complex action of phosphonates as antifungal agents. Biological Review 66:159-187.

Hibbard, J.M., P. Richardson, R. Whitbread, and J.F. Farrar. 1996. Effects of leaf age, basal meristem and infection with powdery mildew on photosynthesis in barley grown in $700 \mu \mathrm{mol} \mathrm{mol}^{-1} \mathrm{CO}_{2}$. The New Phytologist 134:317-325.

Jackson, T.J., T. Burgess, I. Colquhoun, G.E. St, and J. Hardy. 2000. Action of the fungicide phosphite on Eucalyptus marginata inoculated with Phytophthora cinnamomi. Plant Pathology 49:147-154.

Kessmann, H., T. Staub, C. Hofmann, T. Maetzke, J. Herzog, E. Ward, S. Uknes, and J. Ryals. 1994. Induction of systemic acquired disease resistance in plants by chemicals. Annual Review of Phytopathology 32:439-459.

Kraus, T.E., and R.A. Fletcher. 1994. Paclobutrazol protects wheat seedlings from heat and paraquat injury. Is detoxification of active oxygen involved? Plant and Cell Physiology 35:45-52.

MacHardy, W.E., and M.J. Jeger. 1983. Integrating control measures for the management of primary apple scab. Protection Ecology 5: $103-125$.

McNeil, S.D., M.L. Nuccio, and A.D. Hanson. 1999. Betaines and related osmoprotectants. Targets for metabolic engineering of stress resistance. Plant Physiology 120:945-949.

Miller, J.S., N. Olson, L. Woodell, L.D. Porter, and S. Clayson. 2006. Post-harvest applications of zoxamide and phosphite for control of potato tuber rots caused by oomycetes at harvest. American Journal of Potato Research 83:269-278.

Okey, E.N., and T.N. Sreenivan. 1996. Salicylic acid: A factor in systemic resistance of Caco to Phytophthora palmivora. Proceedings of the Brighton Crop Protection Conference. pp. 955-960.

Percival, G.C. 2001. Induction of systemic acquired disease resistance in plants: Potential implications for disease management in urban forestry. Journal of Arboriculture 27:181-193.
Rasmussen, J.B., R. Hammerschmidt, and M.N. Zook. 1991. Systemic induction of salicylic acid accumulation in cucumber after inoculation with Pseudomonas syringae pv syringae. Plant Physiology 97:1342-1347.

Sabri, N., P.J. Dominy, and D.D. Clarke. 1997. The relative tolerances of wild and cultivated oats to infection by Erysiphe graminis f.sp. avanae: II. The effects of infection on photosynthesis and respiration. Physiological and Molecular Plant Pathology 50:321-335.

Sparla, F., L. Rotino, M.C. Valgimigli, P. Pupillo, and P. Trost. 2004. Systemic resistance induced by benzothiadiazole in pear inoculated with the agent of fire blight (Erwinia amylovora). Scientia Horticulturae 101:269-279.

Sticher, L., B. Mauch-Mani, and J.P. Metraux. 1997. Systemic acquired resistance. Annual Review of Phytopathology 35:235-270.

Van Lelyveld, L.J., and H.T. Brodrick. 1975. Enzymic responses of avocado leaves to Phytophthora root rot. Agroplantae 7:13-16.

Van Loon, L.C. 1976. Systemic acquired resistance, peroxidase activity and lesion size in tobacco reacting hypersensitively to TMV. Physiological Plant Pathology 8:231-242.

Vegetti, G.G., C. Conti, and P. Pesci. 1975. Changes in phenylalanine ammonia lyase, peroxidase and polyphenol oxidase during development of local necrotic lesions in pinto beans infected by alfalfa mosaic virus. Phytopathologische Zeitschrift 84:153-171.

Wilkinson, C.J., B.L. Shearer, T.J. Jackson, and G.E. St. J. Hardy. 2001 Variation in sensitivity of Western Australian isolates of Phytophthora cinnamomi to phosphite in vitro. Plant Pathology 50:83-89.

Yancey, P.H. 1994. Compatible and counteracting solutes, pp. 81-109. In: Strange, K. (Ed.). Cellular and Molecular Physiology of Cell Volume Regulation. CRC Press, Boca Raton, FL.

Zhang, P.G., J.C. Sutton, and R.A. Fletcher. 1994. Paclobutrazol protects black spruce seedlings against predisposition to gray mold induced by high temperature and drought. Canadian Journal of Forest Research 24:1033-1038.

\section{Glynn Percival (corresponding author) \\ University of Reading \\ Biological Sciences \\ Bartlett Tree Research Laboratory \\ TOB2, 2 Earley Gate \\ Whiteknights Berkshire \\ Reading RG6 6AU, U.K. \\ gpercival@bartlettuk.com}

Ian Haynes

Arboricultural Representative

Bartlett Tree Experts Company Ltd.

Windmill View

Blackchurch, Rathcoole, County Dublin, Ireland ihaynes@bartlettuk.com

Résumé. Un essai sur le terrain durant deux ans a été mené au moyen de chênes anglais (Quercus robur L.) afin d'évaluer l'efficacité de produits systémiques commercialement disponibles qui permettent d'induire une résistance (acide salicylique, phosphite de potassium, protéine d'harpine, betaine), et ce en les appliquant par vaporisation en tant que traitement thérapeutique contre la maladie foliaire du blanc des feuilles (Microsphaera alphotoides). La résistance systémique permet d'induire des composés contenant de la betaine et une vaporisation unique de penconazole n'a pas eu d'effet significatif sur la sévérité de la maladie, les émissions de fluorescence de la chlorophylle foliaire, le contenu chlorophyllien foliaire et l'activité spécifique du peroxidase et du superoxide dismutase au cours des essais de 2005 et de 2006. L'acide salicylique et le phosphite de potassium n'ont eu aucun effet significatif à long terme sur la sévérité de la maladie, les émissions Fv/Fm de fluorescence de la chlorophylle foliaire et le contenu en chlorophylle 
foliaire tandis qu'une faible diminution de la sévérité de la maladie qui a été enregistrée fut associée avec une amélioration de l'activité en peroxidase et en superoxide dismutase foliaire. Une application thérapeutique unique de l'agent protéine harpine qui induit une résistance systémique a permis de réduire significativement la sévérité du blanc des feuilles au cours de l'essai de 2005 uniquement. Seuls des vaporisations répétitives de penconazole ont permis de diminuer significativement la sévérité du blanc des feuilles chez le chêne au cours des essais de 2005 et de 2006. Une activité foliaire accrue de superoxide disumutase et de peroxidase a été enregistrée suivant les traitements répétitifs avec le penconazole.

Zusammenfassung. Um die Effektivität von kommerziell erhältlichen systemischen Mitteln mit Widerstands-Komponenten (SIR)(Salicylsäure, Kaliumphosphat, Harpinprotein, Betain) in einer einzigen Spray-Anwendung gegen Eichen-Mehltau zu untersuchen, wurde ein zweijähriger Feldversuch an etablierten Englischen Eichen unternommen. In den Versuchen in 2005 und 2006 hatte die SIR-Komponente mit Betain-Anteilen in einer einzigen Spray-Anwendung mit Penconazol keinen besonderen Einfluss auf die Schwere der Krankheit, die Blattchlorophyll-Fluoreszenz-Emissionen, Blattchlorophyll-Gehalt und spezifische Aktivitäten der Peroxidase und Superoxid-Dismutase. Salicylsäure und Kaliumphosphat hatten keinen signifikanten Langzeiteffekt auf die Schwere der Krankheit, die Blattchlorophyll-FluoreszenzEmissionen und den Blattchlorophyll-Gehalt, obwohl kurzfristige Reduktion des Befalls in Verbindung mit verstärkter Blatt-Peroxidase und Superoxid-Dismutase. Eine einzige therapeutische Anwendung von
Harpinprotein reduzierte nur im ersten Versuch 2005 deutlich den Befall. Nur wiederholte Anwendungen von Penconazol konnten in beiden Jahren den Krankheitsbefall reduzieren. Hiernach wurden verstärkte Aktivitäten der Peroxidase und Superoxid-Dismutase beobachtet.

Resumen. Se condujo un ensayo de dos años, usando encinos establecidos (Quercus robur L.), para evaluar la eficacia de sistemas comercialmente disponibles que inducen los compuestos de resistencia (SIR, por sus siglas en inglés) (ácido salicílico, fosfito de potasio, proteína harpin, betaìna); aplicados como un solo tratamiento de aerosol terapéutico contra el patógeno foliar del encino (Microsphaera alphitoides). Los compuestos del SIR que incluyeron betaìna y un tratamiento con aerosol de penconazol no tuvieron influencia significativa en la severidad de la enfermedad, emisiones de fluorescencia de clorofila, contenido de clorofila en la hoja y actividad especifica de peroxidase y superòxido dismutase, en ambos ensayos de 2005 y 2006. El ácido salicílico y el fosfito de potasio no tuvieron efecto significativo a largo plazo en la severidad de la enfermedad, clorofila foliar, emisiones Fv/ Fm y contenido de clorofila en la hoja, a pesar de que fue registrada reducción a corto plazo en la severidad de la enfermedad, que estuvo asociada con la actividad del peroxido y supeoxido dismutate. Una sola aplicación de SIR, induciendo el agente proteínico harpin, redujo significativamente la severidad de la enfermedad, en el ensayo de 2005, únicamente. Aplicaciones repetidas de penconazol, solamente, redujeron significativamente la enfermedad del encino en los ensayos de 2005 y 2006. Se registró una mayor actividad del superoxidase dismutase y peroxidase después de las aplicaciones repetidas de penconazol. 